\title{
Low-Sulfidation Epithermal Carbonate-Base metal-Gold Mineralisation Hosted by Tertiary Sedimentary Rocks in Bastem Prospect, Luwu District, Sulawesi Island, Indonesia: A Preliminary Study
}

\author{
Arifudin Idrus ${ }^{* 1}$, Irzal Nur ${ }^{2}$, Sufriadin ${ }^{2}$, Fadlin $^{3}$, Indra Sanjaya ${ }^{4}$, and Rohaya Langkoke ${ }^{5}$ \\ ${ }^{1}$ Department of Geological Engineering, Faculty of Engineering, Universitas Gadjah Mada, Yogyakarta, Indonesia \\ ${ }^{2}$ Department of Mining Engineering, Universitas Hasanuddin, Makassar, Indonesia \\ ${ }^{3}$ Sudy Program of Geological Engineering, Universitas Jenderal Soedirman, Purwokerto, Indonesia \\ ${ }^{4}$ Geological Survey of Indonesia, Bandung \\ ${ }^{5}$ Department of Geological Engineering, Universitas Hasanuddin, Makassar, Indonesia
}

\begin{abstract}
In Indonesia, gold is typically mined out from epithermal, porphyry and skarn deposit types occurred within volcanic belts along a magmatic arc or active continental margin setting. Numerous gold prospects, however, are recently discovered in association with metamorphic and sedimentary rocks. This paper is aimed to discuss a preliminary study on the occurrences and characteristics of the sedimentary rock-hosted lowsulfidation (LS) epithermal gold mineralisation in Bastem (Bessengan Tempe) prospect, Luwu district, Sulawesi Island, Indonesia. Detailed geological and hydrothermal alteration mapping was performed to understand the distribution and characteristics of ore mineralisation. Representative ore samples taken were analyzed for ore chemistry by means of Fire Assay - Atomic Absorption Spectrometry (FA-AAS) and Acid Geochemical Digest - Atomic Absorption Spectrometry (GA-AAS). The results of this work indicate that the Bastem prospect is stratigraphically occupied by Tertiary sedimentary rocks of Toraja formation, which is adjacent to volcanic rocks of Lamasi formation. Gold-bearing quartz \pm carbonate veins are hosted by mudstone and siltstone of Toraja formation. The quartz-carbonate veins show a typical LS epithermal open space filling texture containing erratic gold grade of up to $7.16 \mathrm{~g} / \mathrm{t}$ with relatively high base metals ( $\mathrm{Pb}$ and $\mathrm{Zn}$ ) grades of up to $>0.4$ and $>1 \%$, respectively. Based on those various features, the LS epithermal deposit is categorized as a carbonate-base metal-gold mineralisation type, which might be originated in a back-arc rift/basin setting. This 'unconventional' sedimentary rock hostedgold mineralisation type would be the new target of gold exploration in Indonesia.
\end{abstract}

Keywords: Sedimentary rocks · LS epithermal gold · Bastem · Sulawesi Island · Indonesia.

\section{INTRODUCTION}

Gold in Indonesia for several decades is typically explored and produced from 'conventional' hydrothermal deposits such as epithermal, porphyry and skarn types occurred within volcanic belts along a magmatic arc or active

\footnotetext{
${ }^{*}$ Corresponding author: A. IDRUS, Department of Geological Engineering, Universitas Gadjah Mada. Jl. Grafika 2 Yogyakarta, Indonesia. E-mail: arifidrus@ugm.ac.id
}

continental margin setting. Recently, gold exploration activities in Indonesia, however, are not only focused along volcanic belt but also starting to shift along metamorphic and sedimentary rock terrain. Some known significant gold-(copper) hydrothermal deposits hosted by volcanic rocks were found in last few decades including epithermal type at Pongkor in West Java (e.g. Basuki et al., 1994; Warmada, 2003), Gosowong in Halmahera Island (e.g. Gem- 
mell, 2007), skarn types at Erstberg, Big Gossan, Kucing Liar, Deep Ore Zone (DOZ) in Papua (e.g. Mertig et al., 1994), and porphyry type at Batu Hijau in Sumbawa Island (e.g. Meldrum et al., 1994; Idrus et al., 2007). Many current discoveries of placer (secondary) and primary gold mineralisation are genetically occurred in association with metamorphic rocks, for instance, Awak Mas mesothermal (Querubin \& Walters, 2011; Ernowo et al., 2019), Poboya LS-epithermal (Wajdi et al., 2011; Rivai et al., 2019), Rampi (Idrus et al., 2016) and Bombana orogenic gold deposits in Sulawesi (Idrus et al., 2017). Gold-bearing quartz veins are also recognized in Derewo metamorphic belt at the northern and northwestern part of Central Range Papua. Some exploration reports categorized the Derewo metamorphic-related quartz veins into mesothermal type. Paningkaban LSepithermal gold deposit located in Banyumas district, Central Java, is hosted by Tertiary turbiditic volcanoclastic sedimentary rocks of the Halang formation (Idrus et al., 2015). The latest discovery during our mining company services is the Bastem LS-epithermal gold deposit, which is hosted by sedimentary rocks of Toraja formation.

This paper is dealing with a preliminary study on the occurrences and characteristics of the sedimentary rock-hosted LS epithermal gold mineralisation in the Bastem prospect in Sulawesi Island. This sedimentary rock hostedgold mineralisation is currently thought to be "unconventional type" and it would be the new target of gold exploration in the backarc basin/rift setting, particularly in eastern Indonesia in the future.

\section{Regional GeOlogy}

Sulawesi Island, formerly known as Celebes Island, is located in the center part of the Indonesian archipelago. Tectonically, Sulawesi Island can be divided into several provinces (Sukamto 1975; Hamilton, 1979; Carlile et al., 1990; Kadarusman et al., 2004): (1) West Sulawesi Plutono-Volcanic Arc (WSPVA), (2) Central Sulawesi Metamorphic Belt, (3) East Sulawesi Ophiolite Belt, and (4) the Banggai-Sula and Buton-Tukang Besi Blocks (Figure 1). The Bastem prospect is sitting on WSPVA. WSPVA contains an almost complete stratigraphic se- quence ranging between Late Cretaceous and recent, which developed in a basement of the continental fragment and accretionary rocks. It represents several major periods of sedimentation, including Late Cretaceous flysch, Eocene syn-rift siliciclastics, Late Eocene-Middle Miocene platform, and deeper marine carbonates, Middle Miocene - Early Pliocene shallow marine deposits, and latest Cenozoic synorogenic sedimentary successions. The sedimentation cycles were interrupted by several magmatic events that took place during the $\mathrm{Pa}$ leocene, mid-Eocene to mid-Oligocene, Early Miocene, and Middle Miocene to Pliocene, locally continuing into the Quaternary (Bergman et al., 1996; van Leeuwen and Muhardjo, 2005; van Leeuwen et al., 2016).

Based on the regional geological map of Majene and western part of the Palopo sheet (Djuri et al., 1998), the study area is composed of four lithostratigraphic formations including the Latimojong formation, Toraja formation, Lamasi volcanic rock and intrusion rocks (Figure 2).

a. Latimojong formation is the oldest rock formation in the study area. The rocks have been experienced weak-moderate metamorphism with the main constituents in the form of shale, phyllite, quartzite, chert, and silicified marble that was intruded by intermediate-mafic igneous rocks. The most common rocks found in the study area are phyllite with gray black in color, plated, hard, and bedding direction of $\mathrm{N} 20^{\circ} \mathrm{E} / 70^{\circ}$ to $\mathrm{N} 80^{\circ} \mathrm{E} / 65^{\circ}$.

b. Toraja formation is unconformably overlain on Latimojong formation. This formation consists of reddish shale, gray marble, limestone, quartz sandstone, conglomerate, and spotted coal. Thickness of formation is $\sim 1,000 \mathrm{~m}$ and is estimated to be Eocene - Miocene.

c. Lamasi volcanic rocks are unconformably overlain on Toraja formation. This formation is composed of andesite, basalt, volcanic breccia, sandstone, and siltstone, locally containing feldspathoid, which is generally silicified and chloritized. This rock formation is estimated to be Oligocene with a thickness of $\sim 500 \mathrm{~m}$.

d. Intrusion rocks are generally composed of 


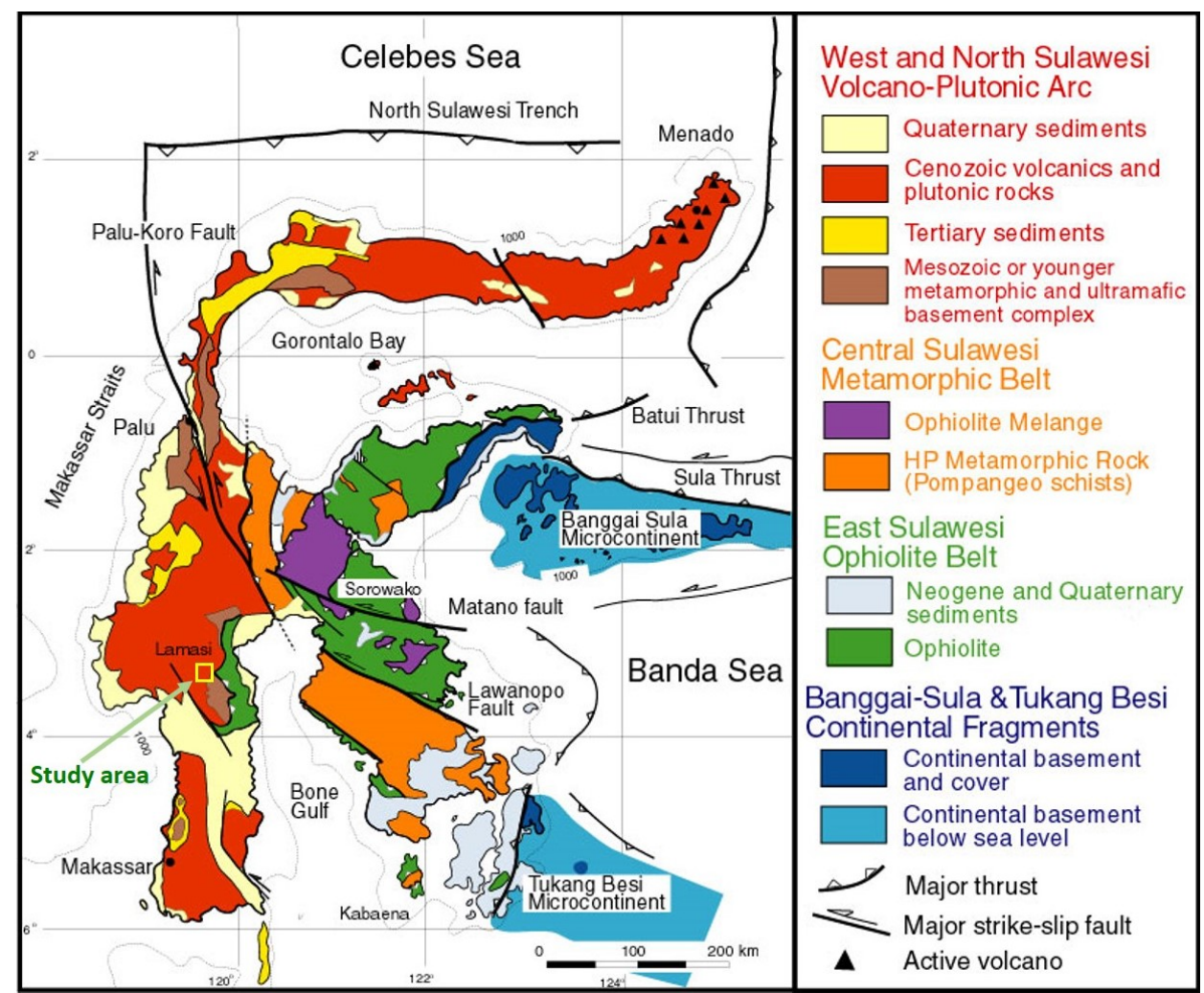

FIGURE 1. Geology of Sulawesi Island (Kadarusman et al., 2004), and study area (Bastem prospect) indicated on the map.

a felsic-intermediate composition consisting of granite, granodiorite, diorite, syenite, quartz monzonite, and rhyolite. This rock unit is thought to be of Pliocene age. Granitic intrusions are scattered in several locations in the northern part of the study area.

\section{ReseARCH Methods}

This preliminary study has been carried out through several approaches, including desk study, fieldwork as well as for ore and mineralised rock sampling for laboratory analysis. Fieldwork was focused on mapping out local deposit geology and hydrothermal alteration and ore mineralisation (quartz vein dimension and orientation). Stream sediment geochemistry was also done during fieldwork, but the data resulted is not discussed in this paper. Mineralogical study of fresh rocks, altered rocks, and ore/vein are only based on an outcrop and megascopic observation of the sample specimens. A total of 20 representative samples of quartz vein and mineralised rocks were collected to be analyzed at the Intertek labo- ratory in Jakarta by means of FA-AAS (Fire Assay-Atomic Absorption Spectrometry) for gold with a detection limit of $0.01 \mathrm{ppm}$. Other elements such as $\mathrm{Cu}, \mathrm{Pb}, \mathrm{Zn}$, and $\mathrm{Ag}$ were analyzed by Acid Geochemical Digest-AAS (GA-AAS) with a detection limit of 2, 4, 2, and 1 ppm, respectively.

\section{Results}

\subsection{Local geology}

The gold prospect area lies in the Bastem sub-district, Luwu district, South Sulawesi province. Morphologically, the studied area is strongly expressed by undulating mountainous terrain with an elevation ranging between $500 \mathrm{~m}$ and 1,400 $\mathrm{m}$ above sea level. The study area is stratigraphically occupied by four rock units consisting of mudstone, limestone, volcanic breccia, and andesite units (Idrus et al., 2011; Figure 3). Some geological structures are developed in this area, mainly fault and joint. Generally, joints have filled by secondary minerals, namely calcite, quartz, adularia, and magnesite. Joints, which have filled by secondary minerals, are common in volcanic brec- 


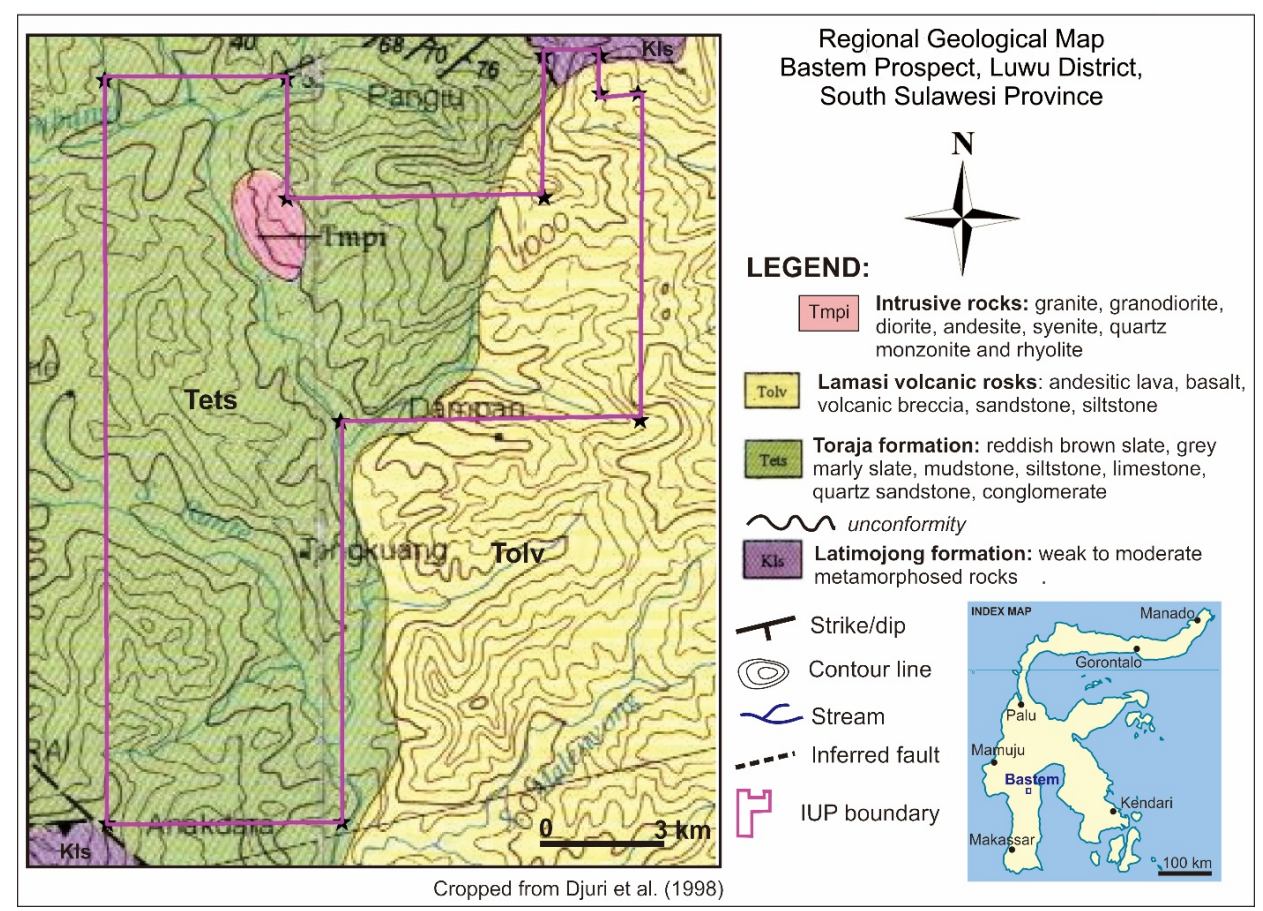

FIGURE 2. Regional geological map (Djuri et al., 1998) of study area which mostly occupied by Toraja formation and Lamasi volcanic rocks (after Idrus et al., 2011).

cias and mudstone units. Based on field investigation, several main geological structures are confirmed in a regular direction relatively northwest-southeast and west-east. Normal and strike-slip faults are indicated by sharp slope and morphology.

\subsection{Hydrothermal alteration}

The alteration type in the surveyed area can be classified into two types, including propylitic and silicification alteration (Idrus et al., 2011; Figure 4). Propylitic or chloritic alteration is the most abundant type (Figure 5A). Pyrite is common in the alteration zone, which occurred as disseminated or in fracture. Silicification in the form of silicified rocks is mostly experienced by the mudstone unit, which is indicated by quartz enrichment due to the hydrothermal process. Quartz veins occur as fracture filling. Several silicification outcrops were found in Taba village, particularly along the Galunturan river (Figure 5B). Silicified rock outcrop, float, or quartz vein fragments are abundantly found along this riverbed. Interestingly, silicified rocks commonly contain carbonate mineral along with quartz in the form of a vein (Figure $5 \mathrm{~A}, \mathrm{~B})$. Carbonate filling is considered a late phase of the hydrothermal process, which oc- curred at low temperatures. Argillic and phyllic alteration is not found in this area, that possibly caused by a narrow distribution or the outcrops have been weathered into the soil and buried by recent deposits.

\subsection{Ore mineralisation and chemistry}

Generally, the distribution of quartz veins in the surveyed area are difficult to delineate, boulders, and float of quartz vein are common. Quartz vein and silicified boulders are white to milky white, subangular to angular, $0.1-2 \mathrm{~m}$ in diameters, very hard, compact, consist of pyrite and very fine sulfide minerals. The quartz+carbonate \pm gold veins are typically characterized by open space filling textures such as saccharoidal, drussy, comb, and banding (crustiform and colloform; Figure 6B). Ore mineralisation is indicated by the presence of pyrite and some base metal sulfides such as galena, sphalerite, chalcopyrite, malachite, and azurite. Arsenopyrite might also be present. Boulders/floats of high mineralised quartz veins have been discovered at the top of the hill slope (Figure 6A) on the north side of the Galunturan river. Two samples were collected, indicating high mineralisation and abundance of sulfides (Figure 6B), particu- 
Low-Sulfidation Epithermal Carbonate-Base metal-Gold Mineralisation Hosted by Tertiary SEdimentary Rocks in BAstem Prospect, LuWu District

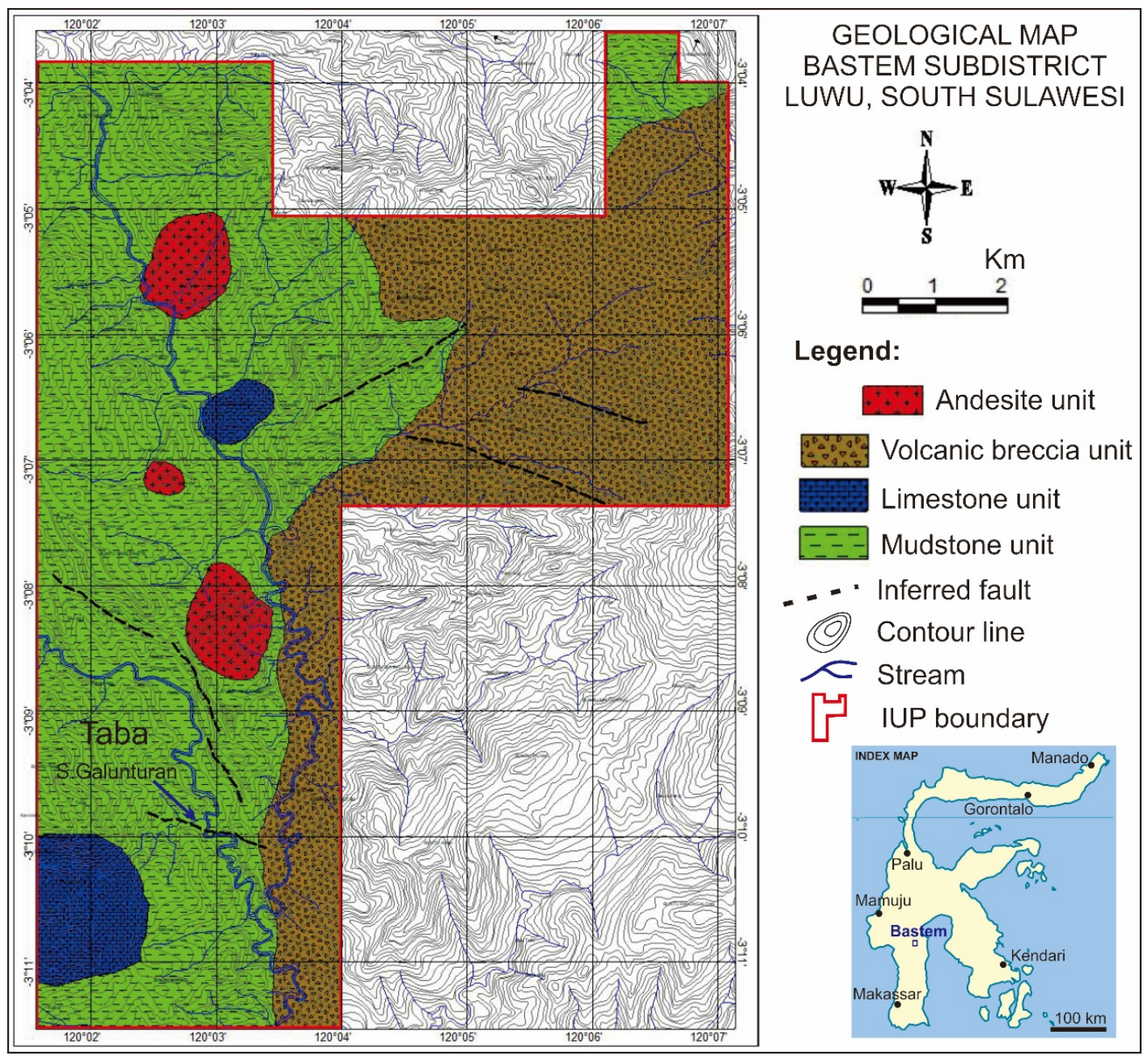

FIGURE 3. Local geological map of the Bastem prospect in Luwu district, South Sulawesi (after Idrus et al., 2011). 


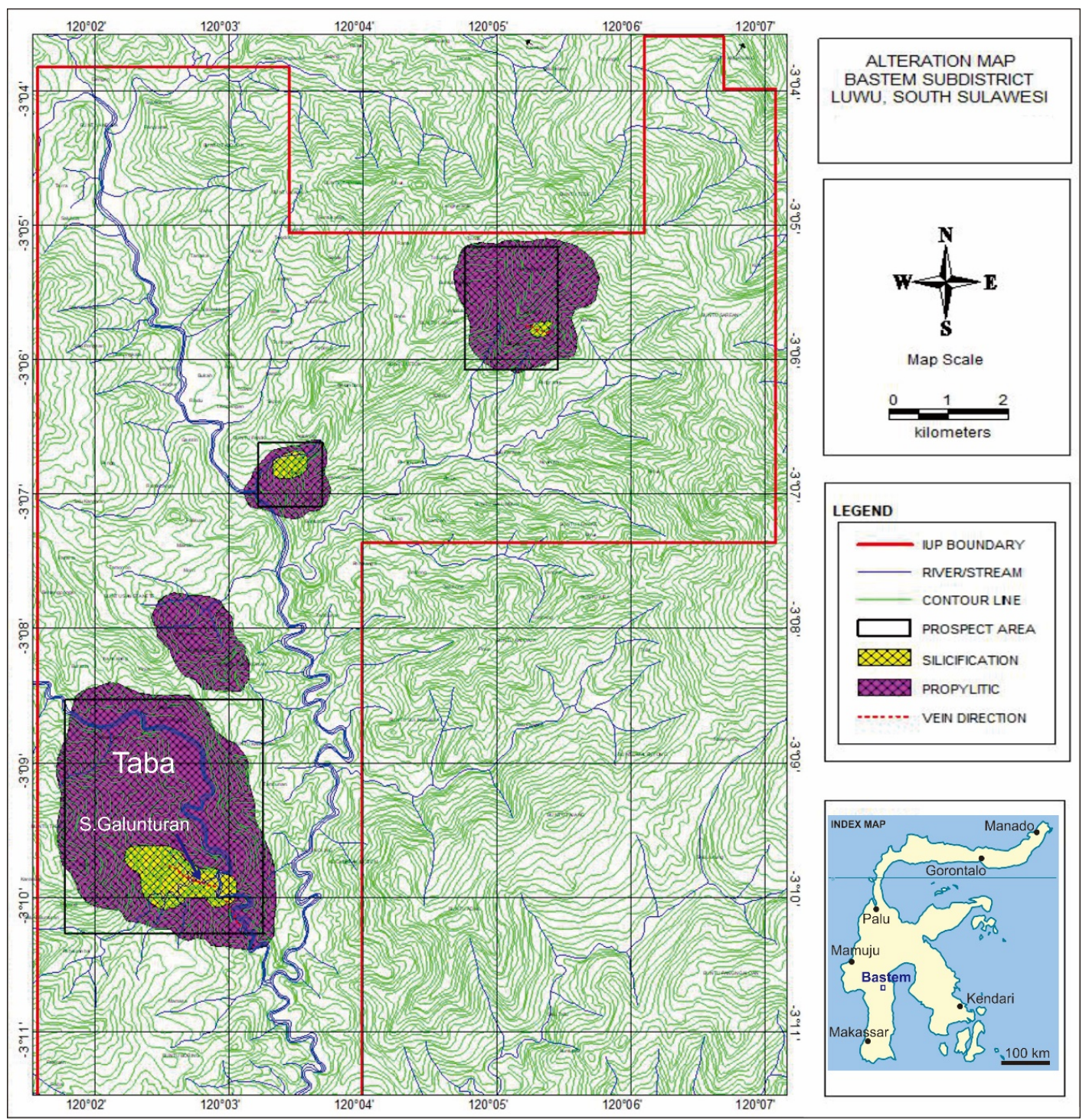

FIGURE 4. Hydrothermal alteration and mineralisation map of the Bastem prospect in Luwu district, South Sulawesi (Idrus et al., 2011).
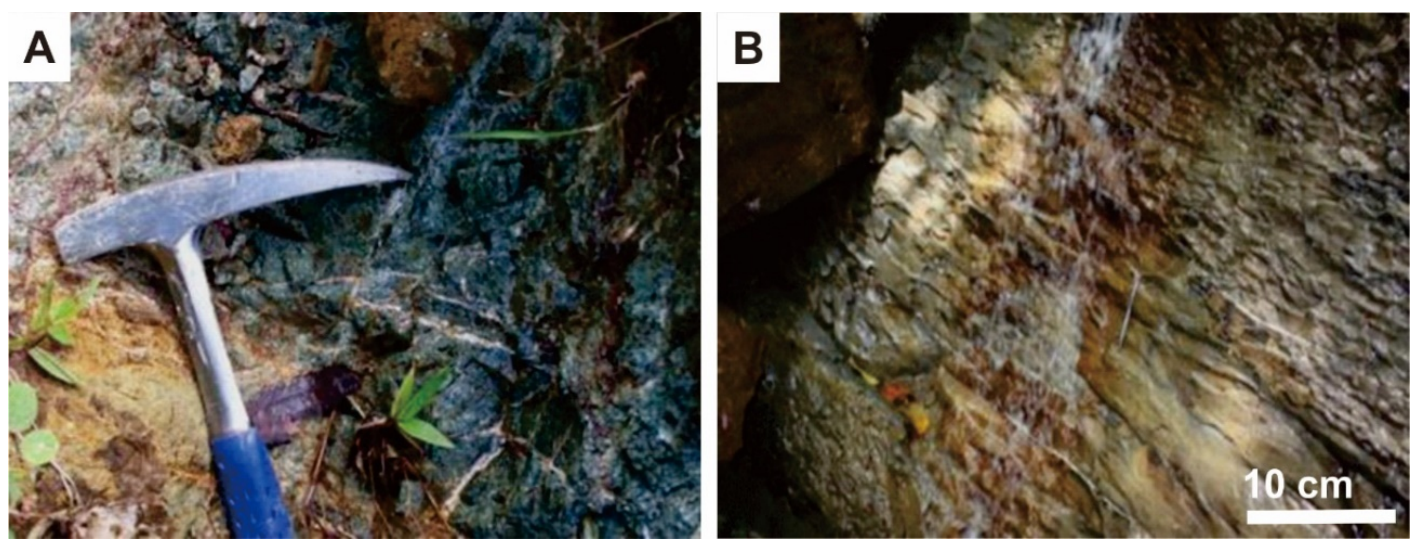

FIGURE 5. Various altered rocks in the Bastem prospect: (A) propylitic/chloritic-altered mudstone, and (B) silicification of mudstone (silicified mudstone). 
larly sphalerite, galena, chalcopyrite, supergene malachite, and azurite. Gangue minerals of the vein are mostly composed of quartz and carbonate (commonly calcite).

The quartz vein boulders are considered as a result of insitu floating of the concealed quartz vein. The source of the boulders could be nearby or buried below the surface. Highly mineralised quartz veins and floats are hosted by or in association with the mudstone unit of Toraja formation in the Galunturan river. No good indications had discovered of quartz veins in volcanic breccia and other units. The quartz veins seem to be strongly controlled by NW-SE trending strike-slip faults. Several quartz veins show typical open space textures in LS epithermal systems such as saccharoidal, drussy, comb, and banding.

A total of 20 selected samples were sent to the Intertek laboratory in Jakarta to be analyzed using FA-AAS for Au and GA-AAS for $\mathrm{Ag}, \mathrm{Cu}, \mathrm{Zn}$, and $\mathrm{Pb}$ (Table 1). Mostly the assay results are below the detection limits for gold $(<0.01 \mathrm{ppm})$, but several samples reveal a good hint where the gold grades are relatively high $(0.01-7.16 \mathrm{ppm})$. An insitu quartz vein float sample taken on the flank of the hill at the northern side of Galunturan river exhibit elevated grade of gold (7.16 ppm Au; Figure 6B) with a high content of base metal elements, i.e., 1,580 ppm Cu, >4,000 ppm $\mathrm{Pb}$; >10,000 ppm $\mathrm{Zn}$ and $17 \mathrm{ppm} \mathrm{Ag} \mathrm{(Sample} \mathrm{A-18A).} \mathrm{This} \mathrm{is}$ in accordance with the megascopic description of the samples showing strongly mineralised vein by the presence of chalcopyrite, sphalerite, galena, malachite, and azurite (Figure 6B).

\section{Discussion}

\subsection{Deposit type}

In general, hydrothermal ore deposits in the study area are characterized by the presence of sulfides with an average abundance of $15 \%$. Sulfide minerals are represented by galena $>$ sphalerite $>$ pyrite $>$ chalcopyrite with gangue minerals, including quartz and carbonate (calcite). Malachite and azurite are also recognized as a product of the supergene process of primary copper sulfides. The gold grain is not observed, but it is significantly present, as shown by assay results. The deposit formed as quartz+carbonate \pm gold veins, which are typically characterized by open space filling textures such as saccharoidal, drussy, comb and banding crustiform, and colloform. Saccharoidal and crustiform textures are shown in Figure 6B. En-echelon extensional fractures produced by NW-SE-trending strike-slip faults might act as opening space for the hydrothermal fluid flow to form gold-bearing quartzcarbonate veins. Lithological type, i.e., sedimentary rocks such as mudstone and siltstone of Eocene-Miocene Toraja formation, played an important role in being favorable host rock for the formation of gold mineralisation. Based on hydrothermal alteration types, ore and gangue mineral associations and characteristics, structures and textures of epithermal veins, and by comparison with existing models (cf. Corbett, 2004; Figure 7), it suggests that the gold deposit occurred in the study area is a carbonate-base metal gold mineralisation sub-type of a LS epithermal system.

However, the volcano-tectonic setting of the Bastem LS epithermal vein might be a backarc rift/basin (not magmatic arc, as shown by Corbett, 2004 model; Figure 7). This is supported by geological facts that the gold-bearing veins are hosted by mudstone and siltstone of Eocene-Miocene Toraja formation, which formed in the shallow marine environment during syn-rifting (Djuri et al., 1998; Calvert and Hall, 2003; Hermiyanto et al., 2010).

\subsection{Implication for exploration}

Current discoveries of sedimentary rock-hosted LS epithermal gold-(base metal) deposits open up more challenges to discover new economic deposits, particularly in Indonesia, particularly in Sulawesi and in eastern Indonesia generally. Sedimentary rocks of Toraja formation formed in the back-arc basin rift environment evidently become to be fertile host rocks for gold mineralisation in the region. This fact is supported by current study results indicate that back-arc basin rift could be a favorable volcanotectonic environment for the formation of an economic LS epithermal gold deposit (e.g., Sillitoe and Hedenquist, 2003; Prihatmoko and Idrus, 2020). Lithologic control and extensional structural deformation forming dilational jogs are the important geological factors for the for- 

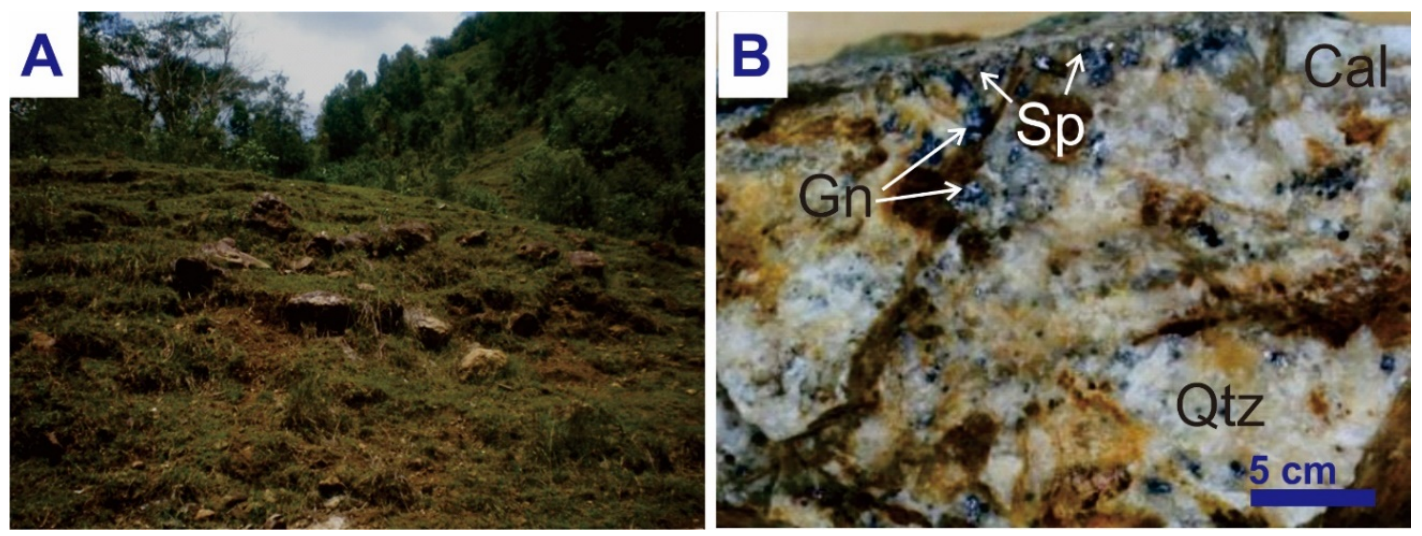

FIGURE 6. Gold-base metals-bearing quartz-carbonate veins: (A) Quartz vein floats found on the hills northern side of Galunturan river, and (B) Specimen of quartz vein float with saccharoidal and crustiform textures containing quartz (Qtz), calcite (Cal), galena $(\mathrm{Gn})$, sphalerite $(\mathrm{Sp})$ and chalcopyrite, supergene azurite and malachite with gold at elevated grade of $7.16 \mathrm{ppm}$ Au.

TABLE 1. FA-AAS assay result of selected samples from Bastem prospect showing an erratic grade (in ppm) of gold and silver as well as base metal elements. Note: Au1 to Au4 indicates repetition of analysis for gold times, respectively.

\begin{tabular}{clcccccccc}
\hline No. & Sample Code & Au1 & Au2 & Au3 & $\mathrm{Au} 4$ & $\mathrm{Cu}$ & $\mathrm{Pb}$ & $\mathrm{Zn}$ & $\mathrm{Ag}$ \\
\hline 1 & A-02A & $<0.01$ & - & - & - & 58 & 10 & 66 & $<1$ \\
2 & A-08 & $<0.01$ & $<0.01$ & - & - & 57 & 6 & 132 & $<1$ \\
3 & A-012 & $<0.01$ & - & - & - & 25 & 23 & 144 & $<1$ \\
4 & A-16 & 0.07 & 0.07 & - & - & 178 & 39 & 48 & 4 \\
5 & A-17A & $<0.01$ & - & - & - & 6 & 9 & 42 & $<1$ \\
6 & A-18A & 7.16 & 5.92 & 7.04 & - & 158 & $>4,000$ & $>10,000$ & 17 \\
7 & A-18B & 0.93 & 1.13 & - & - & 168 & $>4,000$ & 6,14 & 4 \\
8 & A-19A & 0.04 & - & - & - & 63 & 846 & 75 & $<1$ \\
9 & A-19B & 0.01 & - & - & - & 25 & 159 & 100 & $<1$ \\
10 & A-20 & $<0.01$ & - & - & - & 44 & 33 & 44 & $<1$ \\
11 & A-21 & $<0.01$ & - & - & - & 6 & 24 & 76 & $<1$ \\
12 & A-22 & $<0.01$ & - & - & - & 18 & 10 & 34 & $<1$ \\
13 & A-23 & $<0.01$ & - & - & - & 11 & $<4$ & 20 & $<1$ \\
14 & B-09 & 0.01 & - & - & - & 13 & 15 & 29 & $<1$ \\
15 & B-13 & $<0.01$ & - & - & $<0.01$ & 18 & 7 & 64 & $<1$ \\
16 & B-21 & $<0.01$ & - & - & - & 19 & 11 & 73 & $<1$ \\
17 & B-22 & $<0.01$ & - & - & - & 13 & 10 & 96 & $<1$ \\
18 & B-29 & $<0.01$ & - & - & - & 2,690 & 54 & $>10,000$ & $<1$ \\
19 & C-27 & $<0.01$ & - & - & - & 17 & 13 & 29 & $<1$ \\
20 & C-28A & $<0.01$ & - & - & - & 14 & 8 & 61 & $<1$ \\
\hline
\end{tabular}




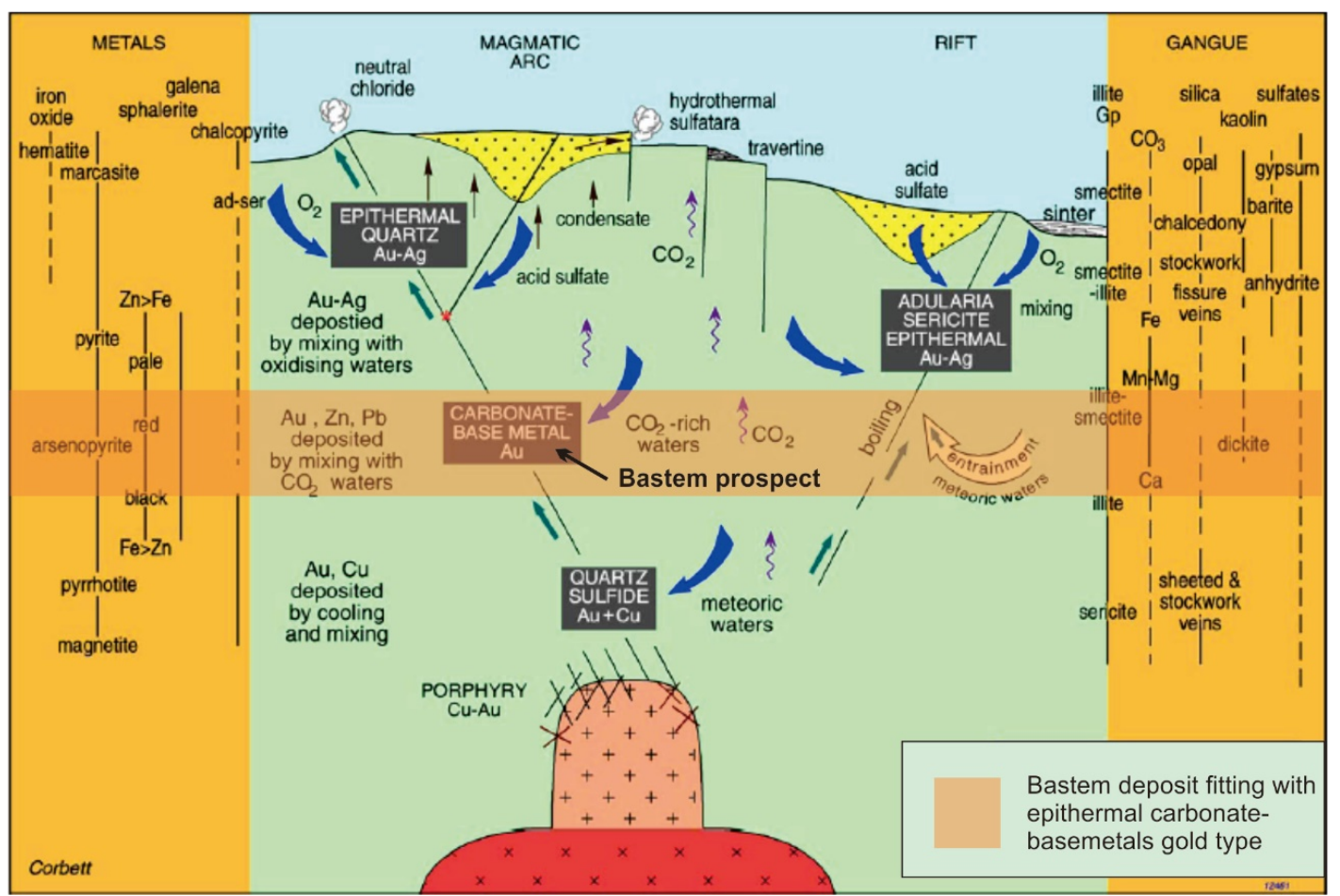

FIGURE 7. Conceptual model of LS epithermal systems (Corbett, 2004), where gold-bearing veins found in Bastem prospect fitting with the LS epithermal carbonate-base metal-gold type.

mation of gold mineralised en-echelon tension gash veins in the LS-epithermal system. A careful study on the deposit geology, hydrothermal alteration, and ore characterization are crucial to be done for an economic evaluation of the deposit since resulted maps, and ore deposit characteristics are needed for designing an effective exploration strategy.

\section{CONCLUSIONS}

a. Gold-bearing quartz veins that occurred in the Bastem prospect are obviously characterized by open space filling textures such as saccharoidal, drussy, comb, and banding, containing gold, pyrite, and base metal sulfides such as galena, sphalerite, and chalcopyrite. Arsenopyrite might also be present in a minor portion. Malachite and azurite occurred as supergene enrichment products of primary copper-bearing sulfides. A gold nugget is not observed megascopically, but its presence is recognized from assay data.

b. Mostly the assay results are below the detection limits for gold $(<0.01 \mathrm{ppm})$, but several samples reveal significant grades, for instance, the best result is shown by
Sample A-18A shows the grade of up to $7.16 \mathrm{ppm} \mathrm{Au}$ in association with a high grade of base metal elements such as 1,580 ppm $\mathrm{Cu},>4,000$ ppm $\mathrm{Pb}$ and $>10,000 \mathrm{ppm} \mathrm{Zn}$. Silver shows a grade of up to $17 \mathrm{ppm} \mathrm{Ag}$. The assay result is in accordance with the megascopic description of the samples showing strongly mineralised vein by the presence of chalcopyrite, sphalerite, galena, malachite and azurite.

c. Two important geological factors are controlling the formation of the LS epithermal gold veins in Bastem prospect, i.e., specific lithological makeup (i.e., interlayered mudstone and siltstone of Toraja formation), and pre- and syn-mineralisation extensional and transtensional structures. Transtensional SW-SE-trending strike-slip fault movements caused dilational jogs manifested by gold mineralised en-echelon tension gash veins.

d. On the basis of hydrothermal alteration types, ore and gangue mineral associations and characteristics, structures and textures of epithermal veins, and by comparison with existing models (cf. Corbett, 2004), it reveals that the gold deposit oc- 
curred in Bastem prospect is a carbonatebase metal gold mineralisation sub-type of a LS epithermal system. Tertiary sedimentary rocks with a back-arc basin rift environment could be a new lithological target for LS epithermal gold exploration in the future in Indonesia, particularly in the regions that are of the similar geologic evolution and structural setting.

\section{ACKNOWLEDGEMENTS}

This work is a part of our mining company services. We thank the management of PT. Emitraco Resources for their permission to utilize the data. The authors fully involved during fieldwork. Hasanuddin and Nurcholis, undergraduate students from Universitas Hasanuddin, took part as field assistant geologists. The authors express deep gratitude and appreciation for their support and effort. We are also thankful to Burwanto from the ESDM office of Luwu district for his hospitality and full support during fieldwork.

\section{REFERENCES}

Basuki, A., Sumanagara, D.A., and Sinambela, D. (1994) The Gunung Pongkor gold-silver deposit, West Java, Indonesia, J. Geochem Expl 50: 371391.

Bergman, S.C., Coffield, D.Q., Talbot, J.P., Garrard, R.A. (1996) Tertiary tectonic and magmatic evolution of western Sulawesi and the Makassar Strait, Indonesia: evidence for a Miocene continentcontinent collision. In: Tectonic evolution of Southeast Asia (eds Hall, R. \& Blundell, D. J.), Geology Society of London Special Publication 106: 391-429.

Calvert, S.J., Hall, R. (2007) Cenozoic evolution of the Lariang and Karama regions, North Makassar Basin, western Sulawesi, Indonesia. Petroleum Geoscience 13: 353-368.

Carlile, J.C., Digdowirogo, S., Darius, K. (1990) Geological setting, characteristics and regional exploration for gold in the volcanic arcs of North Sulawesi, Indonesia. Journal of Geochemical Exploration 35: 105-140.

Corbett, G.J. (2004) Epithermal and porphyry gold - geological models. Proceedings PACRIM Congress 2004, Adelaide. pp. 15-23.

Djuri, Sudjatmiko, S., Bachri, Sukido (1998) Geological Map of Majene and Western Part of Palopo Sheets, Sulawesi, Scale 1: 250,000. Geological Research and Development Centre, Indonesia.
Ernowo, Meyer, F.M., Idrus, A. (2019) Hydrothermal alteration and gold mineralisation of the Awak Mas metasedimentary rockhosted gold deposit, Sulawesi, Indonesia. Ore Geology Reviews, Vol. 113, Pages 103083, https://doi.org/10.1016/j.oregeorev.2019.103083. Gemmell, J.B. (2007) Hydrothermal alteration associated with the Gosowong epithermal $\mathrm{Au}-\mathrm{Ag}$ deposit, Halmahera, Indonesia: Mineralogy, geochemistry and exploration implications, Economic Geology, v. 102, 893-922.

Hamilton, W. B. (1979) Tectonics of the Indonesian region. USGS Prof. Paper 1078, 345 pp.; reprinted with corrections 1981 and 1985.

Hermiyanto, M.H., Mangga, A.M., Koesnama (2010) Lingkungan Pengendapan Batubara, Formasi Kalumpang di Daerah Mamuju. Jurnal Geologi Sumberdaya Mineral 20: 179-184.

Idrus, A., and Kolb, J., Meyer, F.M. (2007) Chemical composition of rock-forming minerals in coppergold-bearing tonalite porphyry intrusions at the Batu Hijau deposit, Sumbawa Island, Indonesia: Implications for crystallisation conditions and fluorine-chlorine fugacity, Special Issue, Resource Geology, V. 57, No. 2 p. 102-113.

Idrus, A., Hakim, F., Warmada, I.W., Aziz, M., Kolb, J., Meyer, F.M. (2015) Geology and Ore Mineralisation of Neogene Sedimentary Rock-hosted LS Epithermal Gold Deposit at Paningkaban, Banyumas Regency, Central Java, Indonesia. J. SE Asian Appl. Geol. 7: 75-81.

Idrus, A., Mansur, S., Ahmad, Rahmayuddin, Mahdi, A. (2016) Occurrences and Characteristics of Gold Mineralisation in Rampi Block Prospect, North Luwu Regency, South Sulawesi Province, Indonesia. Journal of Applied Geology 1: 63-70.

Idrus, A., Prihatmoko, S., Harjanto, E., Meyer, F.M., Nur, I., Widodo, W., Agung, L.N. (2017) Metamorphic rock-hosted orogenic gold deposit style at Bombana (Southeast Sulawesi) and Buru Island (Maluku): Their key features and significances for gold exploration in Eastern Indonesia, Journal of Geosciences, Engineering, Environment and Technology, vol.2, No.2, 2017, p. 124-132.

Idrus, A., Nur, I., Sufriadin, Fadlin, Sanjaya, I. (2011) Laporan Eksplorasi Emas di Bastem, Kabupaten Luwu, PT. Emitraco Resources, Unpublished internal report, 50 hal.

Kadarusman, A., Miyashita, S., Maruyama, S., Parkinson, C.D., Ishikawa, A. (2004) Petrology, geochemistry and plaeogeographic reconstruction of the East Sulawesi Ophiolite, Indonesia. Tectonophysic 392: 55-83.

Meldrum, S.J., Aquino, R.S., Gonzales, R.I., Burke, R.J., Suyadi, A., Irianto, B., and Clarke, D.S. (1994) The Batu Hijau porphyry copper-gold deposit, 
Sumbawa Island, Indonesia: Journal of Geochemical Exploration, v. 50, p. 203-220.

Mertig H.J., Rubin, J.N., and Kyle, J.R. (1994) Skarn $\mathrm{Cu}-\mathrm{Au}$ orebodies of the Gunung Bijih (Erstberg) district, Irian Jaya, Indonesia, Journal of Geochemical Exploration, 50, 179-202.

Prihatmoko, S., Idrus, A. (2020) Low-Sulfidation Epithermal Gold Deposits in Java, Indonesia: Characteristics and Linkage to the Volcano-tectonic Setting. Ore Geology Reviews 212: 103490, https://doi.org/10.1016/j.oregeorev.2020.103490.

Querubin, C.D., Walters, S. (2011) Geology and Mineralisation of Awak Mas: A Sedimentary Hosted Gold Deposit, South Sulawesi, Indonesia, Proceedings of The Sulawesi Mineral Seminar, Manado 28-29 November 2011, p. 211-229.

Rivai, T.A., Yonezu, K., Syafrizal, Sanematsu, K., Kusumanto, D., Imai, A., Watanabe, K. (2019) A Low-Sulfidation Epithermal Mineralisation in the River Reef Zone, the Poboya Prospect, Central Sulawesi, Indonesia: Vein Textures, Ore Mineralogy, and Fluid Inclusions. Resource Geology 69: 385401.

Sillitoe, R.H., Hedenquist, J.W. (2003) Linkages between volcanotectonic settings, ore-fluid compositions, and epithermal precious metal deposits. In: Simmons, S.F., Graham, I.J. (Eds), Volcanic, Geothermal and Ore-forming Fluids: Rulers and Witnesses of Processes within the Earth, Soc. Econ. Geol., Special Publication 10, 315-343, https://doi.org/10.5382/SP.10.16
Sukamto, R. (1975) Perkembangan tektonik di Sulawesi dan daerah sekitarnya, suatu sintesis perkembangan berdasarkan tektonik lempeng. Geologi Indonesia 2: 1-13.

van Bemmelen, R.W. (1949) The Geology of Indonesia. Martinus Nijhoff, The Hague, 102p.

van Leeuwen, T.M., Allen, C.M., Elburg, M., Massone, H.J., Palin, J.M., and Hennig, J. (2016) The Palu Metamorphic Complex, NW Sulawesi, Indonesia: Origin and evolution of a young metamorphic terrane with links to Gondwana and Sundaland. Journal of Asian Earth Sciences, 115, p.133-152.

van Leeuwen, T.M. and Muhardjo (2005) Stratigraphic and tectonic setting of the Cretaceous and Paleogene volcanic-sedimentary successions in Northwest Sulawesi, Indonesia: implications for the Cenozoic evolution of Western and Northern Sulawesi. Journal of Asian Earth Sciences, 25, p.481-511.

Warmada, IW (2003) Ore mineralogy and geochemistry of the Pongkor epithermal gold-silver deposit, Indonesia, Dissertation. Papierflieger, Clausthal-Zellerfeld, $107 \mathrm{p}$.

Wajdi, M.F., Santoso, S.T.J., Kusumanto, D., Digdowirogo, S. (2011) Metamorphic Hosted Low Sulphidation Epithermal Gold System at Poboya, Central Sulawesi: A General Descriptive Review, Proceedings of The Sulawesi Mineral Seminar, Manado 28-29 November 2011, p. 201-210. 